DOI https://doi.org/10.18551/rjoas.2017-02.12

\title{
DEVELOPING MERCHANDISE FOR TOURISM USING PALMYRA PALM LEAF RIBS, PALMYRA PALM LEAVES AND PALMYRA PALM SAP
}

\author{
Sadia I Wayan Suma*, Ketut, Supir I Ketut \\ Faculty of Mathematic and Natural Sciences, Universitas Pendidikan Ganesha, Indonesia \\ *E-mail: prof.iwayansadia@yahoo.co.id
}

\begin{abstract}
This study aimed to understand the reasons why people from Muntigunung and Pedahan, Bali Province, Indonesia, live as beggars and find alternative solutions used to build a good image for the two villages. The results of this study showed that some members of the villages who were formerly beggars had started to show an interest in the activities. They processed the sap of Palmyra palm tree sap not only to sell it to people in the surrounding areas but also were trained to process the sap into crystallized brown sugar to meet the demands of hotels and restaurants.
\end{abstract}

\section{KEY WORDS}

Beggar, products for tourism, Palmyra palm.

Muntigunung and Pedanan villages are located in Kubu District of Karangasem Regency, Bali Province. Geographically, the two villages are in the boundary of Karangasem and Buleleng regencies. The communities of the two villages are known, by Balinese, nationally and internationally, as the villages of origin of the beggars. They spread throughout Bali and beg especially in towns, such as Denpasar, Singaraja, Gianyar, etc. The problem of beggars becomes a serious problem for Karangasem regency and Bali province. Based on the observation result of the Social Department of Bali Province in 1994, the total number of beggar families from Muntigunung and Pedahan is 26, eleven families from Muntigunung and fifteen families from Pedahan. Every year the number of beggars increases. In 2009, the number of families who were beggars from Muntigunung increased to 53 families and from Pedahan to 72.

According to the result of an interview with some public leaders and old people in Muntigunung area (Tianyar Barat village) and Pedahan (Tianyar Tengah village), and the results of researches before, since the old time there has not been any social norm that regulates and orders people from Tianyar (now the village has been split into three: west Tianyar, central Tianyar and east Tianyar) to lead a life as beggars. The behavior of begging is a specific phenomenon in this areas, when compared to the history of beggars from other areas in Bali. It was told that before the natural disaster of the eruption of Mount Agung in 1963, the communities in these areas only knew meurup-urup (bartering with people from the wealthier areas). They used to bring dryland crops, such as corn, nuts, brown sugar, and palmyra palm sap, etc. Bartering was done because of the limitation of natural resources that could be cultivated to meet the basic need of the people, since Muntigunung and Pedahan areas are dry, especially in dry season it is difficult to find water for irrigation and household needs. After doing the barter activity for a while, their behavior gradually changed into beggar's behavior. Begging is done by the way of showing a face that is very suffering, poor, and by carrying small children and even babies and wearing dirty clothes with the hope that this will elicit a pity feeling in the people who see them. They go from door to door in towns and villages which are relatively more fertile and advanced than their village. No one know for sure when exactly the change from barter to begging started.

Various factors cause Muntigunung and Pedahan villagers to make their living by becoming beggars which have been mentioned by many people from various organizations and related parties with the ways of how to solve the problem. However, beggars keep on existing and the number and their spread tend to increase from year to year. As argued by 
various groups of both local and international groups of people in Ubud who call themselves Ubud Community, beggars in Ubud area believe that they exist in an organization who manipulate other people, especially women with limited amount of money that are found in the two villages. While based on an interview and observation made in this study, the local government of Karangasem Regency has tried to solve the problem of begging through the policy of accelerating the process of overcoming poverty problems. The local government of Karangasem solves the beggar problem by engaging various organizations comprehensively in an integrative way. The socioeconomic approach with the focus on welfare has also been done but has not been able to solve the problem. The reality is that up to the present time the beggar problem is still a quite resisting problem.

The major cause of begging behavior in the communities of Muntigunung and Pedahan is low quality human resources. The beggars from the two villages in general (more than $70 \%$ ) never got any formal education, while the rest could have a formal education but did not graduate from elementary school. The low level education can have an implication in the negative behavior of a person, including in meeting his/her life necessities. Thus, in this study an activity was done as a problem solving alternative to control the development of the number of beggars in the villages of Muntigunung and Pedahan. The activity in this study started with the collection of data to understand the reasons they beg. The reasons why some villagers of the two villages become beggars is interesting to be investigated by using critical ethnographic approach, and based on the findings a solution can be given according to the condition of the people and the existence of alternative sources.

Community - Based Tourism which is often used by the tourism actors as reference in developing tourism in Bali should follow the ideas, vision and missions of community-based tourism development. Thus the idea of Cohen and Uphoff (in Prasiasa, 2013) on community participation and its stages need to be understood and applied in developing tourism. Cohen and Uphoff's idea (in Prasiasa, 2013) is as follows:

“...people's involvement in decision making processes, in implementing programs, their sharing in benefits of development programs and their involvement in effort to evaluate the activities in such programs (Cohen and Uphoff, in Prasiasa, 2013)".

The notion of participation of the community members as stated by Cohen and Uphoff above can be used as the basis in developing tourism in Bali that is sustainable and community-based thereby the use of tourism development can be felt by the community in the economic, social and political aspects.

Tourism products are obligatory element in tourism development. Using the idea from Muljadi and Warman (2014) a tourism product is a real and unreal forms in a unit of a series of travels that give good and satisfactory experiences to tourists. To understand the desire of tourists to get a satisfactory service, there are many tourism products in the form of food, drink and handicrafts produced openly. In this case, the tour product entrepreneurs give the opportunity to tourists to come to production centers to see the process of making the tourism products.

Tourism products as everything that can be sold and produced by combining production factors and as something that is offered to consumers including in it a new innovation. Agricultural crops produced the people are very potential to be developed as tourism product ( $\mathrm{Na}$ Songkhla and Somboonsuke, 2012). In this case palmyra palm tree agricultural crop can be processed into brown sugar or various palmya palm plaitings can be made into tourism products by adjusting them according to international tourism products standardization such as easy to carry, clean and hygienic and safe.

\section{METHODS OF RESEARCH}

This article explains about the development of tourism products with leaves, leaf ribs, and sap of Palmyra palm trees as their raw materials to solve beggar community problems in the villages of Muntigunung and Pedahan. The activities done in the effort to solve beggar problems are to develop and diversify dry land various types of tourism products by applying PALS method (participatory action and learning system). Using PALS method it is expected 
that all the beggars are involved directly and actively in the process and evaluation of tourism products development. This activity is expected to have a significant impact on the changing of beggar culture into creative and autonomous culture toward a civil society. The data about the potential of the villages both that are related to natural resources and human resources as well as those that are related to the behaviors of the beggar community in the villages of Muntigunung and Pedahan were collected through survey and was followed up by in-depth interview with the community leaders by using sociological and cultural approach as well as critical ethnographic approach. The data obtained from the findings in the field through research, journals, and relevant books were analyzed descriptive-qualitatively. The data display and the interpretation that is related to the writing of a narrative text and with the quality of thick description in the unity of form, system, patterns, explanation, configuration,, cause and effect order, and proposition, both of those related to a certain display and ideology and dimensions of power or socio politics behind it. The drawing of conclusions or verification includes authentic things, subjective meaning, concept finding, and universal process. The results of data analysis are presented informally in the form of descriptivenarrative format.

\section{RESULTS AND DISCUSSION}

Meaningful Reasons for someone to do the Practice of Begging in Bali. Begging is an activity of begging accompanied by sad appearance is an economic practice done by many people in Indonesia. The phenomenon of the existence of beggars is very difficult to solve, although some solutions have been given by the government and academicians to reduce the number of beggars. The attempt at reducing the number of beggars is also done to improve the image of the areas or the country. The solution to this social problem of begging has to be given comprehensively, which is accompanied by an understanding of the basic reasons why someone does the begging activity as a negative social activity and even it tends to lead to social pathology. As stated by Namwata et al. (2012) that street beggars revealed that mobility of street beggars between places often depends on the availability of income, weather (season), experience of begging life, harmony/disharmony with families/relatives, relations made with friends and circle of contact with other people. The condition that occurs in Muntigunung Village and Pedahan Village have in common, begging is done by some children and even babies, makes some women in the villages it was difficult to leave his life as a beggar. On the other hand the poor their social and cultural quality makes they have no shame as beggars.

Low Quality of Education has an Implication on the Community Cultural- Social Low Level of Awareness. Education is one of the important assets that a person has to own in his/her social life in the society. Bourdieu (in Fashri, 2014) mentions that the intellectual quality produced by education is the form of cultural asset that is very important in improving his/her life quality. While Plummer (2011) mentions that the cultural source owned by someone includes the possession of the ability to access information, knowledge and skill. Plummer introduces a theory that a cultural resource is related to other cultural resources, that is economic, social, symbolic, political, body, and personal resources. The quality of education someone has, that is knowledge and skills are his/her asset in choosing a decent job. On the contrary, the low level of one's education can have an implication in the increasingly low level of his/her bargaining value in selecting a job. The low level education does not only has an implication on the social awareness level. This occurs in two villages, that is Muntigunung and Pedahan villages, Karangasem Regency, Bali Province. The low quality of education traps him/her in a bad life that is to become a beggar. He or she also chooses a job as a beggar because of lack of awareness of the act of begging as a social pathology.

Education is not only obtained by someone from school, but also from family and even the latter is the beginning developer of one's cognitive structure. The low level education owned by a family of course will have an implication in the low level of social awareness socialized in the family. Family has an important role, as mentioned by Syarbini (2016) that 
family is the first and major instituti born of education that plays a very important role in developing the child's trait, character and personality. In the family parents both father and mother become the most important examples for the children. Based on the observation and in-depth interview, it was found that begging spirit is born and formed in the family environment. If the father is a beggar or if the mother is a beggar or if both of them are beggars, then the children tend to become beggars. The activity of begging from Muntigunung and Pedahan villages are mostly done by women. This is quite a cause of concern since as the closest individual to the children psychologically a mother can easily influence the children's way of thinking. A mother who is a beggar tends to cause the children to become beggars too.

A highly educated person, sociologically, tends to have a broader range of occupational choices. Similarly, those with a high self-esteem and prestige. As the consequence, they do not only have a chance to avoid becoming beggars, but they also have a feeling of shame to become ones since beggars do not have a high prestige or becoming a beggar do not conform to their educational backgrounds. Education is the most important asset which Bourdieu categorizes as cultural capital which a person able to present himself in public (Fashri, 2014). On the contrary, a lowly educated person does not feel ashamed to become a beggar. Because the low education limits the chance for him/her to have a decent job in the formal sector. The job vacancies in the informal sector include a beggar. The people choose to be beggars since to be a beggar one does not need to have a diploma; it does not need finance; it does not a sophisticated gadget; it does not need a business permit, etc. (de Soto, 1991). The major capital needed is a willingness to eradicate shamefulness which at the same time means to neglect prestige.

Enhancement of education is one of the endeavor to address the wide spread of beggars. Thus, the Muntigunung village, Kubu district, Karangasem regency custom leaders meeting is held once a month (once in 35 days) on Wage Wednesday (buda wage day) to make a perarem (a customary regulation) about the obligation of the village community members. One of the regulations is compulsory education for children of $7-12$ years old at the primary school. Muntigunung village head stated that the regulation drafted in the meeting of custom leaders had been effective, but it was not yet optimal. This is because the regulation has not had a legal binding, since Muntigunung village, Kubu district, Karangasem regency up to now have not got a legitimate awig-awig (customary rule). Finally, all the activities are only based on pararem the implementation of which is based on the awareness of the krama/village community members themselves.

The process of education starts from the family and mother is very important in to educate children to have autonomous attitude since she is regarded the nearest person to the children. A mother can understand the forms of approaches that have to be used to teach the children. A mother is model for the children to grow, thus if she is practicing begging, then the children will follow her footsteps. The involvement of women, especially those who have been married in begging are caused by some factors such as 1) the people's economic condition is very bad and the incomes that they earn from seasonal farming cannot meet their basic needs; 2) the land that is cultivated is very narrow. Even some of them do not have any cultivated land at all; and 3) the narrow range of jobs available which the local people need.

The fact that there is a narrow range of jobs available for them cannot be separated from their low education. The results show that the most part of beggars $(71.43 \%)$ never had any education, and the rest $(28,53 \%)$ did not graduate from elementary school. In general, this shows a very low quality of capital that the beggars have seen from their educational level. Referring to the research results of lqbali's work (2014) that women mostly (17 people) do the begging Sadia et al. (2016) showed that the number of beggars coming from Muntigunung village is 80 ; and those who came from Pedahan village is 58 , most of them $(70 \%)$ are women. This is not separable from the role of women, especially when they are adults and/or are married structurally have the domestic work, that is managing all that are related to women affairs, are also required to meet the family's everyday life need. They do the begging activities probably because of discoursive and practical influence. The discursive 
awareness refers to one's capability to reflect and to give an explanation to meet their family need. Begging activity will make it easy for them to earn money in such a way that it will sooner or later continually become structured (Giddens, in Priyono, 2002).

The Low Value of Small Change as an Important Factor in the Maintenance of Beggars in Bali. The number of beggars is increasing in cities such as Denpasar because they get money easily. The money that they get is in small changes. This cannot be separated from the low value of small change. People give a low value to small changes especially IDR 1,000 and IDR 2,000 and this opens a business opportunity to others. Based on the interview with someone who does a begging while singing activity around traffic lights in Denpasar, a business opportunity was revealed as follows.

"In every traffic light area I can get money from IDR 1,000 to IDR 5,000 for every time the light turns green. If in an hour this occurs thirty times, then the amount of money that I get in an hour is from IDR 30,000 to IDR 150,000 , then if I work for 8 hours in a day, then my daily income is around IDR 240,000 up to IDR 1,200,000, an good amount of money compared to working at a firm which does not guarantee that you get this much (Deni, 28, interviewed on the $15^{\text {th }}$ of July 2016)."

The fantastic amount of money can be earned by a beggar who begs while singing a song, which if totaled for a month then he or she will get IDR $7,200,000$ up to IDR $36,000,000$. By looking at the fact that the amount earned by the beggar is great, new beggars start to be seen in Denpasar area.

Since the amount of money that one gets by working as pengamen (a singing beggar) makes it very common in many places in Denpasar. This practice has a lot in common with just begging, that is asking for money without working and this act does not need much money.

The small changes issued by the government of Indonesia are actually important means of trading, especially in traditional markets but this has a negative effect. Most of the people at the middle and high class tend to use banknotes of high value in doing a transaction. This causes small changes to be kept and used for other purposes, including giving them freely to the beggars. Borgias (2013) talks about eligo ergo sum which means 'I choose, therefore I exist.' humans as creatures who have a desire always want to exist in the society. Thus, when some people give small changes to the beggars this act communicates the message that they are good people who can donate their money to the poor. Actually the same message could have been expressed by other ways, like by donating money to an orphanage where it is very obvious that there are many children without parents and are in need of money to improve their quality of life, which is not the same as giving money freely to those who regard small money as a business opportunity.

Suyanto (2013) states that contemporary sociology is based on the assumption that an individual's act in economic sector is influenced by social relations. In addition, it is also assumed that the thing that is called an economic act is not always rational-calculative, and is not free from giving material help without considering who is being helped. In addition, the desire to be regarded as a person with a high social spirit is also the goal of a donor, without considering the background of the begging activity and the life that the beggar is focusing at the time he or she is at home from begging. For this reason, a more rational and humane valuation of small change, whatever is the value needs to be improved, since this can cause a negative impact, that is the emergence of structured beggars. On the other hand there is also the assumption that helping the poor including the beggar can provide a positive influence in the life. As proposed Ahmadi (2010) said 'The examination of peoples' attitudes toward begging and beggars indicated that in people's opinion helping beggars can have a positive effects on human life therefore for some social groups such as people of rural social origin and people with low education and married people and those of low education and married people and those of low social classes, the beggars, and their community have a positive function for the society and they have favorable feeling toward them". Thus, the attitude of good people who always gave some money to beggars will be one of the inhibiting factors in solving the problem of beggars. 
Pragmatical Attitude in Meeting the Demand of Lifestyle Makes a Person Justifies the Means to Get Money in an Instant. The choice to be a beggar is seen as an opportunity to get money easily. In general, a begging activity is done by a person with a low social awareness with a pragmatically attitude. Barker (2005) mentions that the pragmatically attitude has become a habit in the society including those who see that to be a beggar one does not need to work hard but can earn money. Although it is realized that to become a beggar is bad, they still keep on becoming one. This cannot be separated from the benefit that one gets without working hard. Especially, when the money earned by begging can exceed the amount one gets after working a full day, and this causes it very difficult to stop the practice without the participation of all people, including those who regard that is better to give small changes to the beggars.

Ignoring the shame or prestige, is done not only because of the fact that one cannot help as the concomitant effect of not having a diploma, but can also be caused by an opportunity and time that one becomes a beggar whose number is high. Formerly, the number of beggars was small and was initiated by the people who could defeat their shameful feeling, but following the human's tendency to like to imitate or follow other's footsteps, then if there is a successful beggar, others will follow his/her footsteps, which causes the increasing number of beggars. So the number of beggars becomes higher and higher. As the consequence, the feeling of shamefulness disappears, because beggars have become a feasible pattern in one's living. Even, it can cause a reversed phenomenon that is people who do not beg become ashamed, since it breaks the general pattern in a community.

Begging behavior in the community is also caused by the act of imitating a friend who is successful in collecting money from begging, this changes the perspective into the one that sees begging as a shortcut to get money. With the begging behavior a symbolic interaction develops. Blumer (in Poloma, 2010) states that a symbolic interaction is geared to three premises: 1) humans react to something based on the meaning of that thing to them; 2) the meaning comes from his or her social interaction with others and 3 ) the meaning is perfected at the time the social interaction takes place. They use ways that shows their miserable conditions or carrying with them babies to make people want to give them money.

The beggar's action in doing his or her activity closely follows the human nature as homo socius, they are not only bound by social structure, that is that they become members of the village or town community, but they also form a begging social system. It means that in doing the begging practice they form a social system, usually formal and neatly organized or the reverse by forming an informal social group (Walgito, 2007). This is very important to meet various needs during the time they are away from home. However, whatever form the group takes, it of course, has values and norms as the morality principle to guarantee the group life.

In whatever form the social system is, the infrastructure that is related to the beggar's life cannot be separated from the ideological super structure. Ideological superstructure is the recipe to act as a beggar in the social structure by involving various aspects of material infrastructure. For example, the power game in the kuren environment (wife environment) can cause a beggar to appear - mother and or children are tied to ideology, that is gender ideology and paternalistic ideology. Even it does not preclude the probability of the role of religion, that is a child obeys his or her parent or a woman obeys her husband, or it can also be caused by Hindu religion. Hinduism orders a woman to respect her husband or a child to respect his or her parents. In the same way the choice of an occupation as a beggar can also be caused by the idea or value system that sees a begging job as feasible (religiously legitimate) seen from the normative principle. When this is related to work ethic, then a beggar can be seen in the work ethic perspective. Does a beggar have a low achievement motivation (McClelland, 1987). Even not less in importance is that a beggar leaves the work in agricultural sector, or it can also be seen from the limitation of the knowledge that the beggars have about agriculture and or other sources of income.

The Involvement of Some Persons in the Community in Beggar Communities in Bali. Beggars in the Muntigunung Village and Pedahan Village are mostly a women. Life stressors 
experienced by women who live in a dry area with various limitations cause them as a beggar. In this study women have a very important role in the movement of beggars in the Muntigunung Village and Pedahan Village. Women who have limited cultural capital such as less of education caused them do not think better before making himself as a beggar. Moreover, they were not understanding the importance of cleanliness in life, causing women in both of the village take their children while practice as beggars. The same findings to Khan, Menka et al. (2013) which explains "Poverty and unemployment are the main problems found among the beggars in the study area along with the problems like irregular supply of water, lack of sanitation, and proper housing condition. The condition of women in the Muntigunung Village and Pedahan Village in addition to having a variety of limitations, they also at under pressure, where their husbands often tell them to beg that the results are used for fun".

Begging done by the people in Muntigunung and Pedahan villages, Karangasem regency, Bali is not only caused by the lack of awareness of the people, low value of small changes, and the pragmatical attitude of the lower class people. This phenomenon also happens because of the pressure from some persons in the community who downgrade women, as implied in the patriarchal ideology. The weak position of women and the strength of patriarchal culture are caused by paternalistic power in the patriarchal culture. The paternalistic power which is indeed the main element in patriarchy directly makes women have under men's control. Men's power in patriarchal culture can be illustrated through Bhasin's account (2002, in Atmadja, 2010) as follows.

"The accurate way to describe men's control over women is through paternalistic power. There is power, but is paternalistic in character since women are given a place to live, food and security vis-a-vis outsiders. Paternalistic power has oppressive aspects, but it also involves a set of mutual responsibilities which are often regarded non-oppressive. It is this that makes it difficult to be recognized and opposed (Bhasin, 2002, in Atmadja, 2010)"

Understanding men's power that is legalized in the patriarchal culture is interesting and needs to be scrutinized, since there are many implications that surface especially in women's life, including female beggars in Muntigunung and Pedahan villages.

The power relation in the family is not less in importance in the context of emergence of beggars. As it happens in Balinese community, in a nuclear family or kuren family (wife family) there is a power relation, that is hierarchically, the power is centered in the father. The father has power over the wife and the children. The father and the mother are parents to the children and have power over them (Atmadja, 2010). Such power relation can easily make the emergence of a beggar. In this context, the father, for example, both because of poverty or laziness or the desire to show that he is the king in the kuren - human behavior is motivated by the desire to hold the power, can easily use his power that is by forcing the wife and children to become beggars. Similarly, the father and the wife as parents, who have power over their children, can easily force them to become beggars.

The force by the father toward his wife and children to become beggars, and similarly the force by the parents toward their children to become beggars do not always mean a physical force or using physical violence commonly called domination, but it can also be done gently or through the rising of cultural awareness called hegemony. Thus, it can be concluded that a person's background to be a beggar is not always due to his or her internal motivation, but can be related to power game that is centered in the father that is directed to the wife and children. The persons who are poor in power, that is, the mother and the children can easily be forced to become beggars by using violence, that is, physical, economic and or symbolic power (Atmadja, 2010).

Power does not only resides in the family, but it also exists in communities, that is desa pakraman and desa dinas. The power attached to desa pakraman - in prajuru desa pakraman and in power in desa dinas is in the hands of the head of the village. The power attached to these officials, actually, can control their residents not to become beggars, both preventively and curatively. But the reality is different, that is they do not care. The cause can be because the power of prajuru desa pakraman and the head of the village is very small so that it is not strong enough for prohibiting the residents to become beggars. Not to mention 
the social relation between him and the resident, for example the close relation between prajuru desa pakraman and the head of the village with the beggars, especially with the pragmatically frame of thought to get some benefit from the begging activity, which can cause the power they have is not used optimally or even is used in a compromise. Such a condition causes the power capital disfunction so that consciously or unconsciously, prajuru desa pakraman and the head of the village who can legally and formally use their power to prevent begging practice act on the opposite way, that is they allow or pretend not to know the existence of beggars and use rationalization to defend themselves.

Alternative Solution in Minimizing the Number of Beggars in Bali. Muntigunung and Pedahan villages are a dry land which causes part of their society choose to live as beggars. The people in the villages pay less attention to what other people say about their so-called profession due to their low education. This research attempts to seek an alternative solution which should imply in the reduction of number of beggars in the two villages.

Developing Handicraft Products Using Local Agricultural Crop as their Raw Materials as an Alternative Solution to Control the Number of Beggars in Bali. Agriculture as one aspect of Balinese culture has to be able to give benefits to the people in tourism. In line with the development of Tourism in Bali that rests on the community's culture, Pitana (2004) stresses that agriculture is the pillar of Balinese cultural life as follows.

"Balinese culture that is inspired by Hinduism generally makes all of the elements of its culture absorbed in Balinese community daily life dominated by agricultural life, so that Balinese culture is an agrarian-based culture. In this case, agrarian culture penetrates all aspects of life such as religious ritual cycles, the contents of material in every ritual, worship of gods so that agricultural life is the pillar of the cultural life (Pitana, 2004)".

Understanding that agriculture is the pillar of Balinese community life makes it necessary to have an appropriate strategy in using agriculture and its products so that through the agricultural life the people can increase their economic welfare, including through creating tourism products from the agricultural products. Purwanto (2009) explains that the agricultural vision in the $21^{\text {st }}$ century is the creation of modern agriculture, that is strong, and efficient. To achieve this the farmers need to be empowered to create farmers who are modern, autonomous, wealthy and fair. Agriculture as an industry that has existed since the old day should receive more attention in order its sustainability can be maintained so that the farmers can be wealthy. The agricultural industry itself, if we focus on it well and if we accept various positive developments, will produce optimal yields. Similarly, the development in science and technology for agriculture produced by academicians and practitioners need to receive attention both from the agricultural community and the government.

Agricultural crops of the community that are processed into tourism products can be categorized as cultural industry. Using the perspective of Frankfurt school, cultural industry is a product produced for mass consumption, in a big number and determines the characteristic of the consumption, in which two characteristics that characterize cultural industry are the presence of standardization and individualism (Suyanto, 2013). Cultural industry can be defined as a culture that has undergone commodification and industrialization. Along with the development of creative industry by the government of Indonesia to improve the economy of the community, cultural industry also undergoes a rapid growth.

Culinary as cultural heritage is a cultural product that is appropriate to be developed since in its development it has a close economic relation with creative industry (Ardika, 2004). Culinary as one of the heritages of Balinese community also experiences commodification and industrialization processes to become cultural product as the development of cultural tourism. In this case, the agricultural products of the community can be processed in such a way to become tourism product of culinary, including palmyra palm tree sap produced from the processing of palmyra palm trees that grow well in the villages of Muntigunung and Pedahan.

Palmyra palm leaves are used to make handicrafts, such as cili (the leaves are plaited into a female figure as the symbol of Dewi Sri) (Covarrubias, 2013). The Cili form is used as a wall decoration, slippers, tissue box, and Hindu ritual facility. The palmyra palm leaf ribs are used to make ingka for fruit stand, spoon place, decorated lamp that are needed by 
hotels, restaurants, and tourist destination areas. The use of palmyra palm leaves and leaf ribs that are available in abundance in nature are cheap if sold as raw materials. The processing of palmyra palm leaves and palmyra palm leaf ribs as souvenirs and as products used by hotels will raise the selling price of the handicrafts of Muntigunung and Pedahan villages. Balinese women actually have the skill in making janur for temple rituals. That skill is a cultural capital that can be used to obtain economic capital, in line with Bourdieu's idea that cultural capital can be exchanged for economic capital and the reverse (Bourdieu, in Fashri, 2014:110). By training the beggar- residents in the villages of Muntigunung and Pedahan in making decoration handicrafts from the leaves and leaf ribs of palmyra palm we can improve their skill (cultural capital) which will be followed by an increase in their economic capital. The ownership of cultural capital and economic capital by the beggar communities in Muntigunung and Pedahan villages will arouse the awareness of "shamefulness culture " and will end with the decrease in the begging activity. The activity in the community service conducted by Sadia et al. (2013) the program called Ipteks bagi Wilayah (IbW) which lasted for three years (2011-2013) showed that humanistic sociological approach and life skills training for beggar community in the villages of Muntigunung and Pedahan could decrease the number of beggars who joined the lbW program by $65 \%$.

The Importance of Involving Women Public Figures in Controlling the Number of Beggars in Bali. Most of the people who become beggars in Muntigunung and Pedahan villages, Karangasem regency, Bali province are women. Most of the women beggars are married with or without children. Ironically, babies are often used by the women when begging, even the babies selected tend to be female. Based on the findings in this study, this is because of the oppression by men who have the position as the heads of the families. They often force their wives and daughters to beg. This fits in the literal meaning of patriarchy given by Bhasin (1996) who defines patriarchy as men's power. In this case, in the community life or family life in the patriarchal culture, whether the members are willing or not to accept it, it is men who hold authority, regulating everything. This is true with women in the villages of Muntigunung and Pedahan villages.

Based on the findings in this study, some women are also aware that a beggar is not a profession but a social pathology that has to be treated in order that it will not happen to the next generations. Women who are aware need a model of women who are public figures and capable of creating a piece of work which can be exchanged for money. In this context, there is need for the role of women who have a strong capital to drive other women who are still beggars to change profession into craftswomen by creating various handicrafts using agricultural products as their raw materials. Various forms of activities done by women in the two villages both by women who have never been beggars and those who are beggars as shown in Figure 1 below.

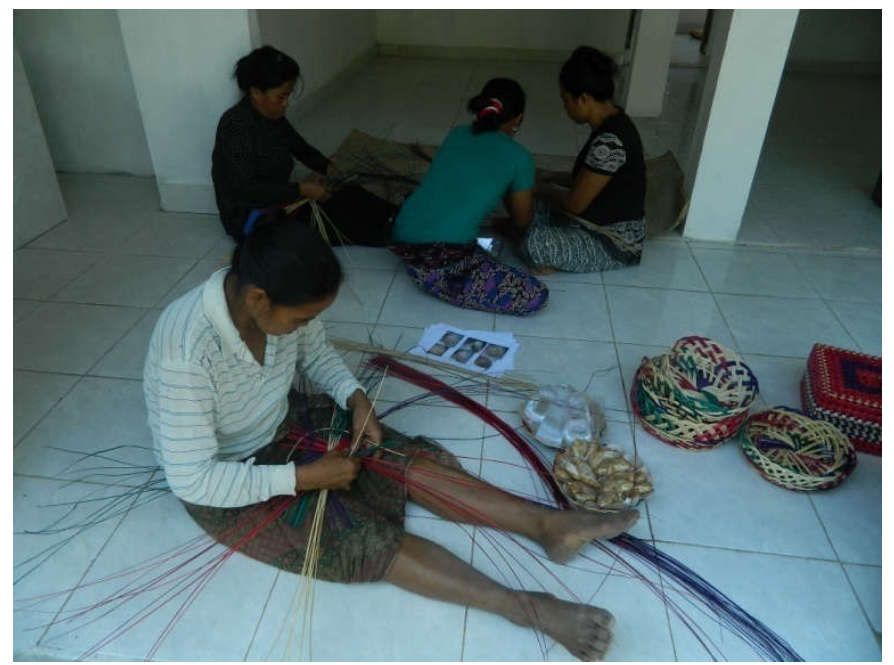

Figure 1 - Women in Muntigunung Village Who are Making Handicrafts Using Palmyra Palm Tree Agricultural Products as their Raw Materials 
In this study, the approach to the women in Muntigunung Village was done to change the paradigm of thinking that begging activities are activities that are bad. In this study, women are taught to process agricultural products into the tourism product. It is similar to that performed by Namwata et al. (2014) in his article titled "Consequences of Begging and Future Aspiration of Beggras to Stop Begging Life in Central Tanzania". Namwata et al. (2014) said "The most effective approach to solving the issue to street begging is trough counseling. It is a process of helping beggars to engage in better choices in order to have future plans and aspirations to get rid off begging life. Counseling can also help beggars to be assertive and in the process become asset instead of liabilities to their families and society at large. In this case, counselors can apply their skills in vocational, educationalsocial counselling will enable beggars to explore alternative ways off utilizing their acquired skills". In the course of this research, women in the Muntigunung Village and Pedahan Village invited to Developing Merchandise for Tourism by Using Palmyra Palm Leaf Ribs,Palmyra Palm Leaves and Palmyra Palm Sap.

The Importance of the Acceptability of Products Produced by the Beggar Community by Tourism Industry. The acceptability of handicrafts produced by the beggar community in the villages of Muntigunung and Pedahan by tourism industry is very important. It is important that their products be widely accepted, including by tourism industry, the major industry in Bali, including Karangasem regency and this will have an impact on their perspective in which they believe that they can earn money by using a better way. To reach this goal, the roles of various parties: the government, tourism industry actors and academicians are needed in order that the products produced by the beggar communities can have a direct impact on their economic life. In order the products produced can become tourism industrial products, the way how the products is presented has to conform to the needs and demands of tourism. To achieve this objective the writers did in-depth interview in some starred hotels to find out the types of products that can be developed by the communities in the villages of Muntigunung and Pedahan, Karangasem Regency, Bali Province.

Tourism products are the obligatory elements in developing tourism. In Muljadi and Warman (2014) it is explained that tourism products are the real and unreal things in the series of tours that can only be enjoyed when all of the series can offer good and satisfying experiences to the tourists. In this context, the tourism products meant can take the form of goods and services. Food, beverages a handicrafts produced by Balinese people can also be categorized as tourism products. Understanding the tourists' desire to get satisfying services, now there are many tourism products like food, beverages and handicrafts that are produced openly. In this case, the tourism product centers give an opportunity to the tourists to come to the centers to see the process of making the tourism products. It is this that becomes an added value to the tourism products. Government, especially at the district level of government in this regard is expected to be a medium that helps in the marketing of products produced by the people in the Muntigunung village and Pedahan village, so that the sustainability of the production will be able to overcome the problem of beggars who have switched as artisans. As proposed Namwata et al. (2014) that likewise, the local and central governments must support beggar by integrated methods, based not only on prohibition, but also on a range of job offers.

Kotler and Amstrong (1989) gives us a perspective that agricultural products produced by farmers have a great potential to be developed into tourism products. In this case, Palmyra palm tree agricultural products that are processed into brown sugar or other kinds of plaited work can be presented as international tourism products which are easy to carry, clean and hygienic and safe.

\section{CONCLUSION}

The development of handicrafts using local agricultural products (leaf ribs, leaves and sap of Palmyra palm trees) can become an alternative in controlling the number of beggars who spread over Bali. In the light of observation in the field it is clear that the existing 
agricultural products in the villages of Muntigunung and Pedahan, Karangasem Regency, Bali can be processed into various handicrafts and the raw material for food. The communities in the two villages who focus on the making of the tourism products are mostly women. They need to be oriented to choose the processing of agricultural products rather than to become beggars, although they can collect more money from the begging activity.

The involvement of women in developing the handicrafts is very important, considering that so far the number of women beggars is significantly numerous. The nature of human as an imitating creature is one of the factors why a person chooses a job. Thus in developing the women groups who are socially aware and capable of earning much money through creating handicrafts has to be done intensively, in order that the women who are still beggars are interested in being involved in the activity and gradually can leave their jobs as beggars.

The acceptability by tourism industry in Bali of the products produced by the beggar community to stimulate women not to be beggars any longer is very important to be done. With the acceptance of the products produced by the communities in Muntigunung and Pedahan villages, especially for those who are ex-beggars by tourism industry can become an appeal to other women beggars to be involved in the production of the handicrafts. The economic benefit felt directly through the sale of the handicrafts as tourism products will give them a deep understanding that there are better jobs than becoming a beggar.

\section{REFERENCES}

1. Ahmadi, H. (2010). A Study of Beggars Characteristics and Attitude of People towards the Phenomenon of Begging in the City of Shiraz. Journal of Applied Sociology, 39 (3): 135-148.

2. Ardika, I.W. (2004). Pariwisata Bali: Membangun Pariwisata Budaya dan Mengendalikan Budaya Pariwisata dalam Bali Menuju Jagadhita: Aneka Perspektif. Pustaka Bali Post, Denpasar.

3. Atmadja, N.B. (2010). Komodifikasi Tubuh Perempuan Joged "Ngebor" Bali. Pustaka Larasan, Denpasar.

4. Barker, C. (2005). Cultural Studies Teori dan Praktek. Translated by Tim Kunci Cultural Studies Center. Bentang, Yogyakarta.

5. Bhasin, K. (1996). Menggugat Patriarkhi Pengantar Tentang Persoalan Dominasi Terhadap Kaum Perempuan. Yayasan Bentang Budaya, Jakarta.

6. Borgias, F.M. (2013). Manusia Pengembara:Refleksi Filosofis tentang Manusia. Jalasutra, Yogyakarta.

7. Covarrubias, M. (2013). Pulau Bali: Temuan yang Menakjubkan. (ed. Jiwa Atmaja).Udayana University Press, Denpasar.

8. De Soto, H. (1991). Masih Ada Jalan Lain Revolusi Tersembunyi di Negara Dunia Ketiga. Yayasan Obor, Jakarta.

9. Fashri, F. (2014). Pierre Bourdieu: Menyingkap Kuasa Simbol. Jalasutra, Yogyakarta.

10. Khan, J.H., Menka, and Shamshad. (2013). Problems of Beggar: A Case Study. International Journal of Management and Social Sciences Research. 2 (12): 67-74. ISSN: 2319-4421.

11. Kotler, P. and Armstrong, G. (1989). Principles of Marketing. NJ: Prentice Hall.

12. Muljadi, A.J. and Warman, A. (2014). Kepariwisataan dan Perjalanan. PT. Raja Grafindo Persada, Jakarta.

13. Na Songkhla, T. and Somboonsuke, B. (2012). Impact of agro-tourism on local agricultural occupation: A case study of Chang Klang district, southern Thailand. Journal of Agricultural Technology, 8(4): 1185-1198. ISSN 1686-9141.

14. Namwata, B.M.L and Mgabo, M.R. (2012). Feeling of Beggars on Begging Life and Their Survival Livelihoods in Urban Areas of Central Tanzania. International Journal of Physical and Social Sciences. 2 (2): 306- 322. ISSN: 2249-5894.

15. Namwata, B.M.L and Mgabo, M.R. (2014). Consequences of Begging and Future Aspiration of Beggras to Stop Begging Life in Central Tanzania. International Research Journal of Human Resources and Social Science. 1 (4): 176-187. ISSN: 2349-4085. 
16. Pitana, I.G. (2004). Mispersepsi Pemberdayaan Masyarakat dalam Kepariwisaaan Bali. Bali Post, March 2004: 7.

17. Plummer, K. (2011). Sosiologi The Bacis. Raja Grafindo Persada, Jakarta.

18. Prasiasa, D.P.O. (2013). Destinasi Pariwisata Berbasis Masyarakat. Salemba Humanika, Jakarta.

19. Poloma, M. (2010). Sosiologi Kontemporer. PT Raja Grafindo Persada, Jakarta.

20. Priyono, B.H. (2002). Anthony Giddens: Suatu Pengantar. Kepustakaan Populer Gramedia, Jakarta.

21. Purwanto. (2009). Pertumbuhan dan Hasil Empat Varietas Padi (Oryza sativa L.) pada Sistem Pertanian Organik, Semiorganik dan Pertanian Konvensional. Thesis Agronomi. Universitas Gadjah Mada, Yogyakarata.

22. Sadia, W., Suma, K. and Supir, K. (2016). Pengembangan serta Diversifikasi Hasil Pertanian Lahan Kering Menjadi Produk Wisata sebagai Alternatif Percepatan Pertumbuhan Ekonomi Masyarakat Gepeng Muntigunung dan Pedahan, Kabupaten Karangasem-Bali. Laporan Penelitian MP3EI Universitas Pendidikan Ganesha.

23. Sadia. (2013). IbW Muntigunung dan Pedahan. Laporan Akhir Ipteks bagi Wilayah (IbW) Universitas Pendidikan Ganesha.

24. Suyanto, B. (2013). Sosiologi Ekonomi Kapitalisme dan Konsumsi di Era Masyarakat Post-Modernisme. Kencana Prenada Media Group, Jakarta.

25. Syarbini, A. (2016). Pendidikan Karakter Berbasis Keluarga: Studi tentang Model Pendidikan Karakter dalam Keluarga Perspektif Islam. Ar-Ruzz Media, Yogyakarta.

26. Walgito, B. (2007). Psikologi Kelompok. Andi Offset, Yogyakarta. 